\title{
The occurrence of the coronuloid barnacle Chelonibia Leach, 1817 as an encruster on mammalian bone in the central Mediterranean Sea
}

\author{
Alberto COLLARETA ${ }^{1,2 *}$ and Giovanni BIANUCCI ${ }^{1,2}$ \\ ${ }^{1}$ Dipartimento di Scienze della Terra, Università di Pisa, via S. Maria 53, Pisa 56126, Italy \\ ${ }^{2}$ Museo di Storia Naturale, Università di Pisa, via Roma 79, Calci 56011, Italy \\ *Corresponding author, e-mail: alberto.collareta@unipi.it
}

\begin{abstract}
Among the turtle and whale barnacles (Coronuloidea: Chelonibiidae, Coronulidae, †Emersoniidae and Platylepadidae), the members of the chelonibiid species Chelonibia testudinaria (Linnaeus, 1758) are known as epizoic barnacles that can attach to a rather wide spectrum of substrates (primarily sea turtles, crabs and sirenians). At present, three living morphs of $\mathrm{C}$. testudinaria have been recognised; of these, the less host-specific is the patula morph, which also displays a remarkably simple, unspecialised shell architecture. Here we report on several chelonibiid shells, referred to the patula morph of $\mathrm{C}$. testudinaria, encrusting a cetacean scapula collected from the floor of the Adriatic Sea facing Salento (Apulia Region, southeastern Italy) and tentatively referred to Tursiops truncatus (Montagu, 1821). This is one of the few records worldwide of a coronuloid barnacle from an inanimate substrate, as well as the second as an encruster on mammalian bone. Such an unusual occurrence is then briefly discussed in the broader framework of the coronuloid commensalism and substrate habits.
\end{abstract}

Key words: Cirripedia; Chelonibiidae; epibiosis; host preferences; symbiosis; turtle barnacle

\section{INTRODUCTION}

The acorn barnacles (Crustacea: Thoracica: Balanomorpha) included in the cirriped superfamily Coronuloidea are known as epibionts of several saltwater vertebrates and, secondarily, invertebrates (e.g., DARWIN, 1854; GRUVEL, 1905; PILSBRY, 1916; KRÜGER, 1940; NEWMAN, 1996; LIU \& REN, 2007). Members of Coronuloidea are currently assigned to four families, namely, Coronulidae, Chelonibiidae, Platylepadidae, and the puzzling †Emersoniidae (NEWMAN, 1996; COLLARETA \& NEWMAN, 2020). The coronulids, which are commonly referred to as the "whale barnacles', are regarded as obligate commensals of cetaceans; conversely, the chelonibiids and platylepadids (collectively known as the 'turtle barnacles') are relatively more generalist as regards their host habits, although most of them preferentially inhabit the skin or shell of the sea turtles (chelonians) (e.g., ROSS \& NEWMAN, 1967; ROSS \& FRICK, 2011; HAYASHI, 2013, and references therein).

The sole living genus of Chelonibiidae, Chelonibia, includes two extant species, namely, Chelonibia testudinaria (Linnaeus, 1758) and 
Chelonibia caretta (Spengler, 1790); two other living species (i.e, Chelonibia patula (Ranzani, 1817) and Chelonibia manati Gruvel, 1903) were also recognised as valid until a few years ago, but have recently been revealed as comprising peculiar morphs of $C$. testudinaria (CHEANG et al., 2013; ZARDUS et al., 2014). At present, Chelonibia caretta has only been reported as an epibiont on sea turtles, either on the chelonian shell or skin; in turn, $C$. testudinaria is an epizoic barnacle whose morphs can attach onto a relatively broad range of substrates, including marine and brackish-water turtles, crabs and horseshoe crabs, sea cows, sea snakes, crocodilians, sea snails, and even inanimate substrates such as floating plastic items (e.g., DARWIN, 1854; ROSS \& JACKSON, 1972; NEWMAN \& ROSS, 1976; MONROE \& GARRET, 1979; FRAZIER \& MARGARITOULIS, 1990; BADRUDEEN, 2000).

Here we report on several shells of the patula morph of Chelonibia testudinaria encrusting a cetacean scapula collected from the floor of the Adriatic Sea facing Salento (Apulia Region, southeastern Italy). This is one of the few records worldwide of a coronuloid barnacle from an inanimate substrate, as well as the second as an encruster on mammalian bone. The herein reported occurrence is then briefly discussed in the broader framework of the coronuloid commensalism and substrate habits.

\section{MATERIAL AND METHODS}

This paper describes the unusual association between a cetacean scapula and several chelonibiid barnacle shells that adhere to its outer cortical surface. This bone and its crustacean encrusters are currently kept in the zoological collection of the Museo di Storia Naturale dell'Università di Pisa (hereinafter: MSNUP) under the accession number MSNUP C 3240. They were recovered by the late Angelo Varola $(\dagger 2019)$ from a shallow seafloor off the eastern (i.e., Adriatic) coast of Salento, between Brindisi and Santa Maria di Leuca (Apulia Region, southeastern Italy) (Fig. 1). Although the precise locality of MSNUP C 3240 is unknown, its provenance - the Adriatic Sea facing Salento - is ascertained.

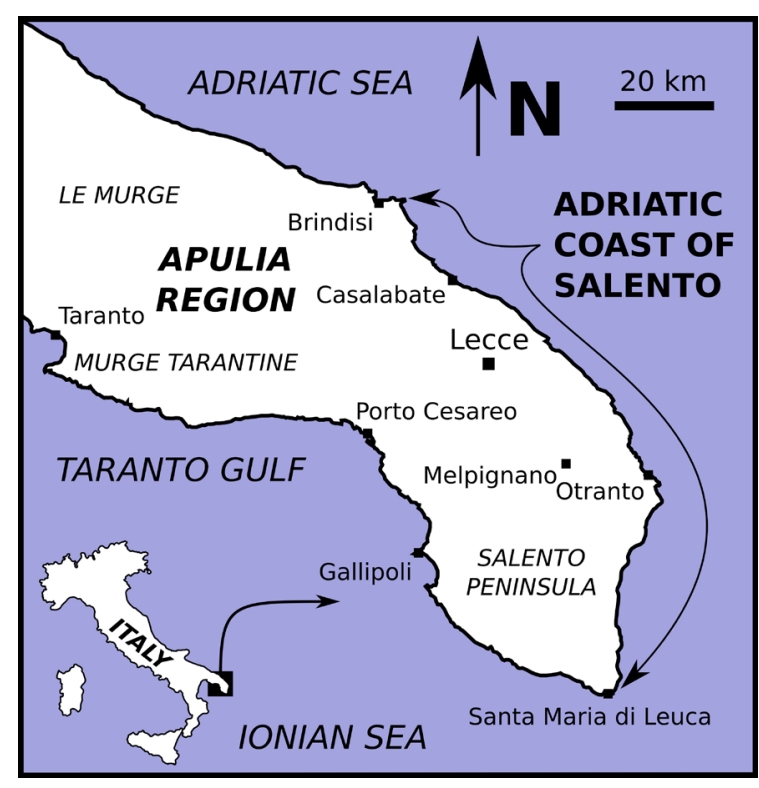

Fig. 1. Map of the Salento peninsula (Apulia Region, southeastern Italy), showing the extent of the Adriatic coast of Salento, from which the cetacean and chelonibiid specimens described herein have been collected. Modified after PERI et al. (2019)

The anatomical terminology follows MARX et al. (2016) as regards the cetacean scapula, and various works by DARWIN (1854), PILSBRY (1916), ROSS \& NEWMAN (1967), NEWMAN \& ROSS (1976), HARZHAUSER et al. (2011) and COLLARETA et al. (2016) as regards the coronuloid specimens.

Measurements were taken using a standard analog caliper. Photographs were taken using a Nikon D5200 digital camera.

\section{RESULTS}

MSNUP C 3240 consists of a partial left scapula of a cetacean that lacks most of its dorsal portion (Fig. 2). Comparisons between this bone and shoulder blades of extant Mediterranean cetaceans kept at the MSNUP allowed for highlighting strong morphological similarities with the scapula of the common bottlenose dolphin Tursiops truncatus (Montagu, 1821).

On the preserved portion of the lateral surface of the scapula (Fig. 2A), an acorn barnacle lies close to the posterior border of the blade. This is an eight-plated, truncated-conical, carinorostrally elongated shell displaying a maximum basal diameter of $9.0 \mathrm{~mm}$. The true ros- 


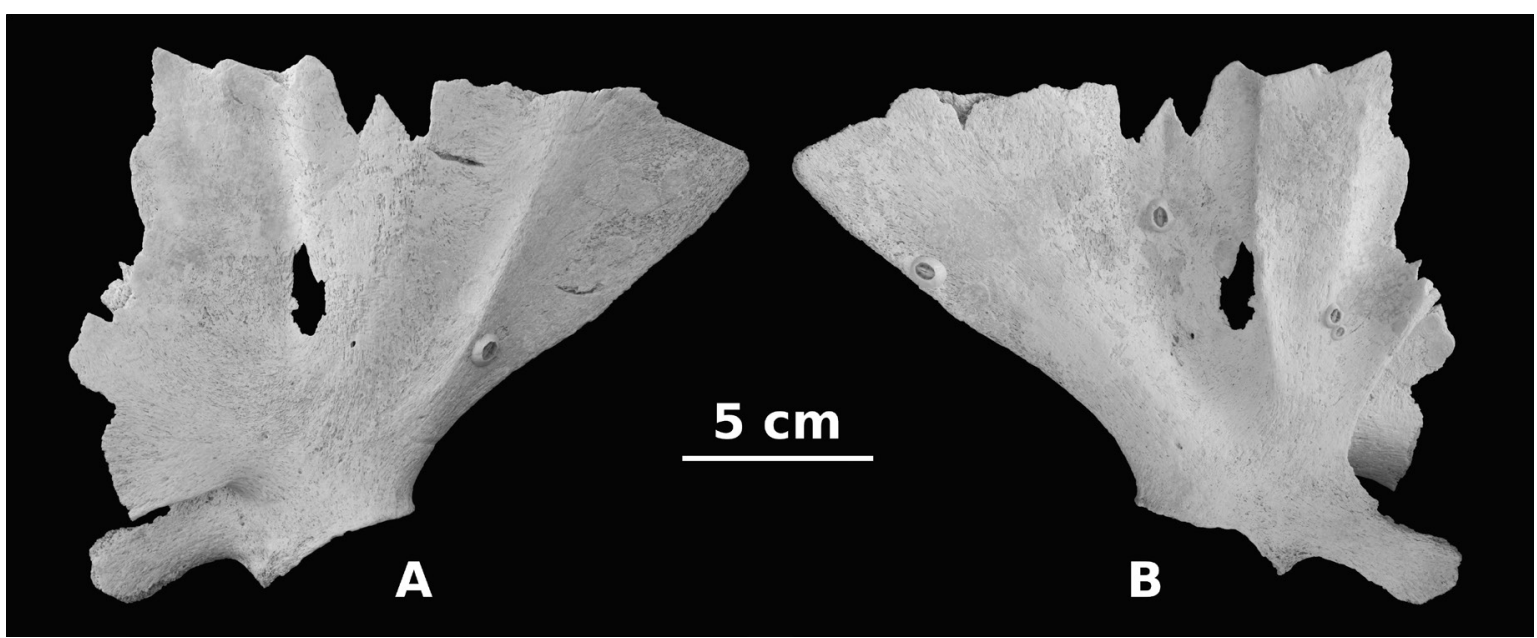

Fig. 2. MSNUP C 3240, partial cetacean scapula from the floor of the Adriatic Sea facing Salento, in (A) lateral and (B) medial views.

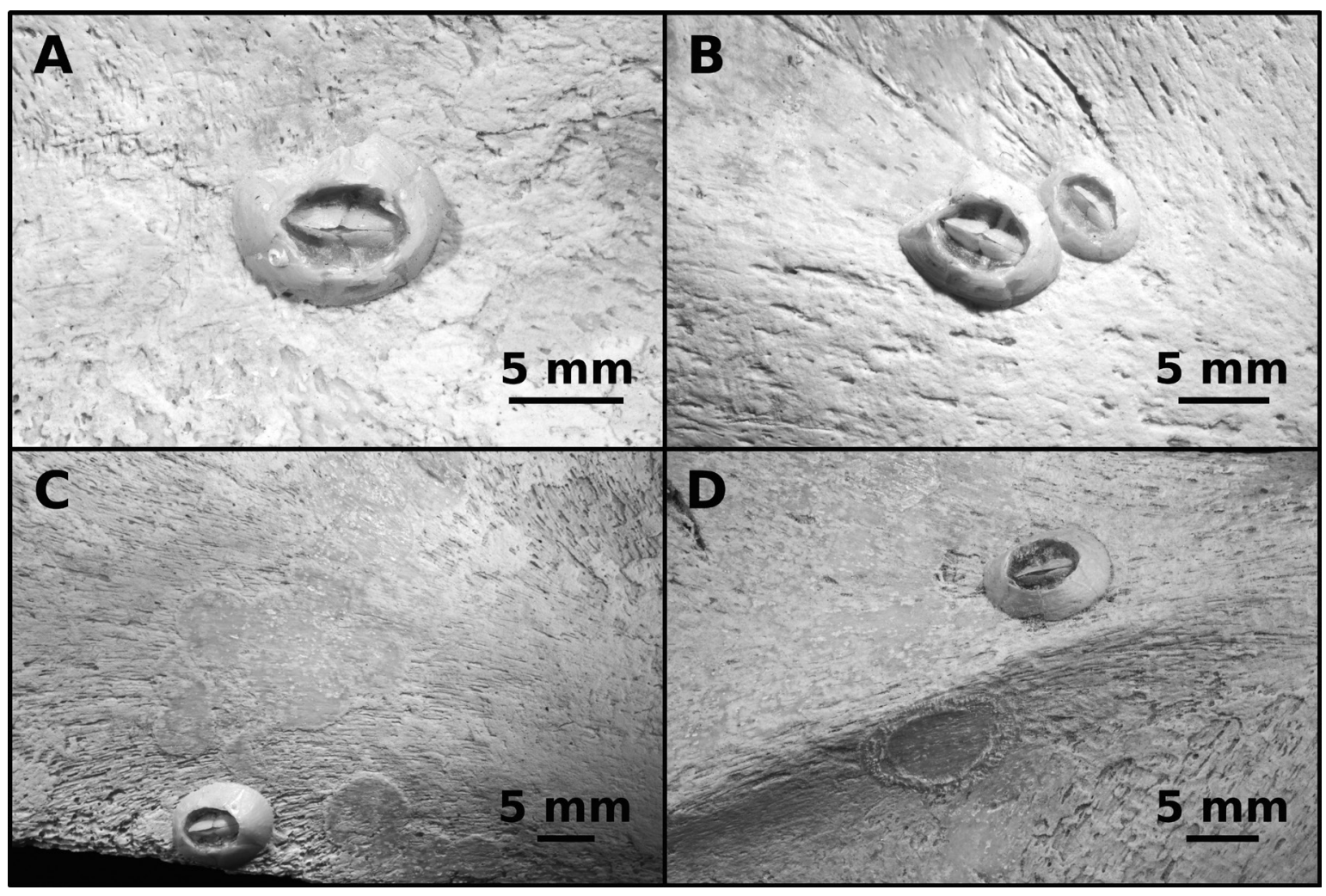

Fig. 3. Close-ups of five shells of Chelonibia testudinaria (patula morph) occurring as encrusters on the partial cetacean scapula MSNUP C 3240. (A) Detail of a chelonibiid specimen occurring on the medial surface of the shoulder plate (note the locally concave basal profile that indicates the adjoining occurrence of another barnacle shell that did not get preserved). (B) Detail of two chelonibiid specimens that cluster on the medial surface of the shoulder plate (note the locally concave basal profile of the larger specimen). (C) Detail of a chelonibiid specimen occurring on the medial surface of the shoulder plate (note the nearby presence of clusters of barnacle attachment traces). (D) Detail of a chelonibiid specimen occurring on the lateral surface of the shoulder plate (note the nearby presence of a barnacle attachment trace, still exhibiting shreds of the membranous basis that also reveal a dense pattern of longitudinal internal parietal septa). All the chelonibiid specimens are here depicted with their rostral end facing rightwards. 
trum and rostrolaterals are partially coalescent with each other to form a tripartite rostral complex. The parietes are thin and delicate, and the substantially smooth radii are only slightly sunken. The external surfaces of the parietes are almost featureless. The opercular plates are strongly reduced. On the whole, these characters allow for the identification of the patula morph of Chelonibia testudinaria, a member of the coronuloid family Chelonibiidae (e.g., DARWIN, 1854; PILSBRY, 1916; ROSS, 1963; NEWMAN \& ROSS, 1976; CHAN et al., 2009; CHEANG et al., 2013; ZARDUS et al., 2014).

Four similar barnacle specimens are found on the preserved portion of the medial surface of the scapula (Fig. 2B); in particular, one of them (measuring $9.3 \mathrm{~mm}$ in carinorostral diameter) is observed along the posterior border of the blade, two (measuring 6.4 and $4.3 \mathrm{~mm}$ in carinorostral diameter) cluster close to the anterior border of the blade, and the fourth (measuring $9.3 \mathrm{~mm}$ in carinorostral diameter) takes its place in an intermediate position. Two of the aforementioned specimens display a locally concave basal profile that indicates the adjoining occurrence of another barnacle shell that did not get preserved (Fig. 3A, B). All the observed barnacles have their carinal extremity oriented towards the unpreserved dorsal margin of the scapula.

Furthermore, traces that are found on both the lateral and medial surfaces of the shoulder blade hint at the former presence of several more encrusting barnacle shells that detached from the scapula before it was collected from the seafloor (Fig. 3C). These traces range between 5.9 $\mathrm{mm}$ and $11.8 \mathrm{~mm}$ in maximum diameter. They consist of oval patches where the outer cortical surface is seemingly well preserved and appears as slightly lifted above the partly abraded surrounding areas. These traces superficially recall the barnacle attachment marks that have been classified under the ichnogeneric name Anellusichnus (SANTOS et al., 2005; BUCKERIDGE et al., 2019), and especially Anellusichnus circularis Santos, Mayoral \& Muñiz, 2005. A few traces still exhibit shreds of soft tissues (i.e., the membranous basis of the barnacle) attached to them, which in one case also reveal the dense pattern of longitudinal internal parietal septa that is typical of Chelonibia (Fig. 3D). Seven traces are observed on the lateral surface of the scapula, whereas more than 25 traces occur on the medial surface of the bone (including the medial surface of the acromion). Most of these traces form clusters (Fig. 3C). The greater abundance of barnacles and barnacle attachment traces on the medial surface of the scapula might be due to this bone having rested at the seafloor medial side-up (see also BIANUCCI \& GINGERICH, 2011 in this respect).

\section{DISCUSSION AND CONCLUSIONS}

Encrustation of defleshed mammalian bones by acorn barnacles is a relatively common occurrence, as demonstrated by a rather conspicuous amount of observations (e.g., SACCO, 1893; DENNISON et al., 2004; BOESSENECKER, 2013; POKINES \& HIGGS, 2015; TSAI et al., 2017; BOSIO et al., 2021). What is peculiar to the present report is the assignment of the encrusting barnacles to the superfamily Coronuloidea, whose members are currently understood as obligate or quasiobligate phoronts of several different marine organisms. To our knowledge, the herein record of several chelonibiid specimens assigned to the patula morph of Chelonibia testudinaria as encrusters on mammalian bone represents the second of its kind worldwide. Indeed, a similar occurrence was reported by MONROE (1981) as follows:

"Specimen lot W7354, Chelonibia patula, 20 individuals, was removed (together with 20 Balanus trigonus W7355) from a human femur recovered in $20 \mathrm{~m}$ from Moreton Bay [Australia, authors' note] near Moreton Is. on July 10th 1977. It may be that Chelonibia patula has a substrate preference involving organised calcium matrices."

In another passage, MONROE (1981) characterised the bone on which the Chelonibia shells attached as "old". MONROE (1981) did not figure these specimens, neither did others; in addition, no further records of Chelonibia or other coronuloid barnacles attaching to a bony substrate are known to the authors of the present work. 
In light of these considerations, our discovery represents a rather important find that deserves to be adequately reported on.

More than 37 barnacle specimens were originally attached to the dolphin scapula. Those among them that managed to get preserved display no signs of abnormal growth as well as a much ordinary size. Therefore, coupled with the results by MONROE (1981), our observations suggest that the association between the patula morph of $C$. testudinaria and the defleshed mammalian bone is far from being anomalous, the latter likely representing a much suitable (although ostensibly rare) substrate for the attachment of the former. That said, the reduced opercular plates that characterise the coronuloids (including all the living members of the genus Chelonibia) and the consequent exposure of the soft parts to predators might partly explain why the patula morph of $C$. testudinaria is only occasionally found on motionless (but otherwise hospitable) substrates such as bone.

Whereas the testudinaria and manati morphs of $C$. testudinaria are largely if not exclusively confined to sea turtles and sea cows, respectively, the patula morph is capable of exploiting a broad diversity of potential substrates, including vertebrates, invertebrates and inanimate objects (both artificial ones, such as plastic, and dead biological materials, such as bone; MONROE, 1981; FRAZIER \& MARGARITOULIS, 1990; this work). The greater host specialisation of the manati and testudinaria morphs of C. testudinaria is mostly achieved via a number of modifications that are related to the attachment mechanisms: for instance, the former can send finger-like ramifications of the periphery of its wall plates into the somewhat penetrable skin of its sirenian host (ROSS \& NEWMAN, 1967; FRICK et al., 2011), whereas the latter even displays remarkable post-settlement capabilities of locomotion that are believed to derive from specialised contractile fibrils connecting the barnacle shell to its membranous basis, which in turn contacts the underlying turtle shell (MORIARTY et al., 2008). Overall, the patula morph of C. testudinaria represents the less specialised living form of coronuloid barnacles, as is also reflected by its altogether simple shell architecture (NEWMAN \& ROSS, 1967; ZULLO, 1982) that does not deviate strongly from the overall aspect of an 'average' non-epizoic, rock-dwelling balanomorph barnacle. While apparently at odds with the recent synonymisation between $C$. patula and C. testudinaria (CHEANG et al., 2013), the persistence of a peculiar morph characterised by a generalised shell architecture allowing for diverse substrate habits and a high host plasticity might have comprised a key factor in determining remarkable species longevity in C. testudinaria as redefined by ZARDUS et al. (2014) (see also COLLARETA, 2020 in this respect). Interestingly, recruitment experiments in conditions of relatively low flow rates (i.e., those achievable on overall stationary test panels) demonstrate that larvae of $C$. testudinaria can successfully settle, metamorphose and grow on a wide variety of sub-optimal substrates (including pieces of carapace scutes from dead turtles, slate, and even Plexiglas $($ )), with the resulting shells ultimately acquiring a patula-like morphology (SLOAN et al., 2014). Therefore, low hydrodynamism seemingly correlates with the occurrence of the patula morph of C. testudinaria on slowly moving hosts such as molluscs, crabs and horseshoe crabs (CHEANG et al., 2013; SLOAN et al., 2014), and the same could be true for inanimate substrates such as bone. That said, the role and contribution of genetics, substrate nature, hydrodynamism, and other environmental parameters in controlling the adult morphology of $C$. testudinaria still have to be properly investigated.

The above considerations about the unspecialised nature of the patula morph of C. testudinaria also suggest that the soft- and hard-part morphology of this form might represent a pivotal research target for reconstructing how and from where the unique host specialisations of the remainder of Coronuloidea (ROSS \& NEWMAN, 1967; SEILACHER, 2005; KIM et al., 2020) evolved. Furthermore, they raise the question of whether the earliest members of this superfamily were preferential or obligate eipibionts on nektic and benthic-vagile hosts like their modern relatives, or they rather were encrusters or episkeletozoans on inanimate substrates (either biogenic 
or abiogenic). Whereas sea turtle fouling was reconstructed on the basis of indirect evidence for the early Miocene (ca. 22 million years ago) species $\dagger$ Protochelonibia submersa Harzhauser \& Newman in HARZHAUSER et al., 2011 as well as for the early or middle Miocene $\uparrow$ Chelonibia zanzibarensis Collareta \& Newman in COLLARETA et al., 2021, there is still no hint of what sort of hosts the geologically older taxa $\uparrow$ Emersonius cybosyrinx Ross in ROSS \& NEWMAN, 1967 and $\uparrow$ Protochelonibia melleni (Zullo, 1982) might have been on (COLLARETA \& NEWMAN, 2020).

All things considered, in the quest for the causes and processes beneath the emergence of epibiosis and commensalism in the so-called turtle and whale barnacles, the patula morph of C. testudinaria promises to serve as a crucial object of study.

\section{ACKNOWLEDGEMENTS}

The material studied herein was collected and stored at the Università di Pisa by the late Angelo Varola (Università del Salento), whom we remember with the greatest gratitude and affection. Chiara Sorbini (Museo di Storia Naturale dell'Università di Pisa), Cecilia Vianello (Museo di Scienze Naturali di Venezia), Claire Mellish (Natural History Museum of London) and Gianni Insacco (Museo Civico di Storia Naturale di Comiso) are kindly acknowledged for granting access to the extant and extinct coronuloid material under their care. The prominent scientific illustrator Alberto Gennari amicably shared with us his knowledge on the provenance of MSNUP C 3240. Simone Farina (Museo di Storia Naturale dell'Università di Pisa) also deserves our gratitude for his valuable curatorial support.

Among several other colleagues who generously contributed their views on the fossil history of the superfamily Coronuloidea, the late William "Bill" Newman (MBRD, Scripps Institution of Oceanography), Mark Bosselaers (Koninklijk Belgisch Instituut voor Natuurwetenschappen) and Ray T. Perreault (Jarreau Scientific) are also warmly thanked for several fruitful discussions in the fields of the biology and palaeontology of the genus Chelonibia. Not least, constructive criticisms by John S. Buckeridge (RMIT University), an anonymous colleague, and the journal editor Anita Marušić (Institute of Oceanography and Fisheries) greatly contributed to shape this paper in its present form - thank you very much!

Shortly before the acceptance of the present paper, Bill Newman sadly passed away: by building upon Bill's seminal researches, our work contributes to testify to his extraordinary stature as a scientist whose life-long quest for knowledge has been (and will always be) exemplary.

The research of AC is supported by a LinnéSys: Systematics Research Fund grant (funded by the Linnean Society of London and the Systematics Association).

\section{REFERENCES}

BADRUDEEN, M. 2000. On the occurrence of the cirriped barnacle, Chelonibia patula (Ranzani) on the sea snake, Hydrophis cyanocintus (Daudin). Mar. Fish. Inf. Serv. Tech. Ext. Ser., 164: 25.

BIANUCCI, G. \& P. D. GINGERICH. 2011. Aegyptocetus tarfa, n. gen. et sp. (Mammalia, Cetacea), from the middle Eocene of Egypt: clinorhynchy, olfaction, and hearing in a protocetid whale. J. Vertebr. Paleontol., 31 (6): 1173-1188.
BOESSENECKER, R.W. 2013. Taphonomic implications of barnacle encrusted sea lion bones from the Middle Pleistocene Port Orford Formation, coastal Oregon. J. Paleontol., 87: 657-663.

BOSIO G., A. COLLARETA, C. DI CELMA, O. LAMBERT, F. G. MARX, C. DE MUIZON, A. GIONCADA, K. GARIBOLDI, E. MALINVERNO, R. VARAS-MALCA, M. URBINA \& G. BIANUCCI 2021. Taphonomy of marine vertebrates of the Pisco Formation (Miocene, Peru): Insights into the origin of an outstanding Fossil- 
Lagerstätte. PLOS ONE, in press (DOI: 10.1371/journal.pone.0254395).

BUCKERIDGE, J., T. KOČÍ, J. SCHLÖGL, A. TOMAŠOVÝCH \& M. KOČOVÁ VESELSKÁ. 2019. Deep-water cirripedes colonizing dead shells of the cephalopod Nautilus macromphalus from New Caledonian waters. Integr. Zool., 14 (6): 561-575.

CHAN, B.K.K., R.E. PRABOWO \& K.S. LEE. 2009. Crustacean fauna of Taiwan: Barnacles, Volume 1, Cirripedia: Thoracica excluding the Pyrgomatidae and Acastinae. National Taiwan Ocean University, Keelung, 298 pp.

CHEANG, C.C., L.M. TSANG, K.H. CHU, I.J. CHENG \& B.K.K. CHAN. 2013. Host-specific phenotypic plasticity of the turtle barnacle Chelonibia testudinaria: a widespread generalist rather than a specialist. PLoS One, 8: e57592.

COLLARETA, A. 2020. Discovery of complemental males in a Pliocene accumulation of Chelonibia testudinaria (Linnaeus, 1758), with some notes on the evolution of androdioecy in turtle barnacles. N. Jb. Geol. Paläontol., 297: 193-203.

COLLARETA, A., M. BOSSELAERS \& G. BIANUCCI. 2016. Jumping from turtles to whales: a Pliocene fossil record depicts an ancient dispersal of Chelonibia on mysticetes. Riv. Ital. Paleontol. S., 122 (2): 35-44.

COLLARETA, A. \& W.A. NEWMAN. 2020. Protochelonibia melleni (Zullo, 1982) comb. nov., an archaic barnacle from the lower Oligocene of Mississippi (USA), and its impact on the stratigraphic and geographic distribution of the early coronuloids of Western Tethys. Boll. Soc. Paleontol. Ital., 59: 179-181.

COLlARETA A., W.A. NEWMAN, G. BOSIO \& G. COLETTI. 2021. A new chelonibiid from the Miocene of Zanzibar (Eastern Africa) sheds light on the evolution of shell architecture in turtle and whale barnacles (Cirripedia: Coronuloidea). Integr. Zool., in press (DOI: 10.1111/1749-4877.12554).

DARWIN, C. 1854. A Monograph on the Sub-class Cirripedia with Figures of all the Species. The Balanidae, the Verrucidae, etc. Ray Society, London, 684 pp.

DENNISON, K.J., J.A. KIESER, J.S. BUCKERIDGE \&
P.J. BISHOP. 2004. Post mortem cohabitationshell growth as a measure of elapsed time: a case report. Forensic Sci. Int., 139: 249-254.

FRAZIER, J.G. \& D. MARGARITOULIS. 1990. The occurrence of the barnacle, Chelonibia patula (Ranzani, 1818), on an inanimate substratum (Cirripedia, Thoracica). Crustaceana, 59 (2): 213-218.

FRICK, M.G., J.D. ZARDUS, A. ROSS, J. SENKO, D. MONTANO-VALDEZ, M. BUCIOPACHECO \& I. SOSA-CORNEJO. 2011. Novel records and observations of the barnacle Stephanolepas muricata (Cirripedia: Balanomorpha: Coronuloidea); including a case for chemical mediation in turtle and whale barnacles. J. Nat. Hist., 45: 629-640.

GRUVEL, J.A. 1903. Revision des Cirripèdes appartenant à la collection du Muséum d'Histoire Naturelle (Operculés). II. Partie systématique. Nouv. Arch. Mus. Nat. Hist. Nat., 45: 95-170.

GRUVEL, J.A. 1905. Monographie des Cirrhipèdes ou thecostracés. Masson et Cie, Paris, 472 pp.

HARZHAUSER, M., W.A. NEWMAN \& P. GRUNERT. 2011. A new Early Miocene barnacle lineage and the roots of sea-turtle fouling Chelonibiidae (Cirripedia, Balanomorpha). J. Syst. Palaeontol., 9 (4): 473-480.

HAYASHI, R. 2013. A checklist of turtle and whale barnacles (Cirripedia: Thoracica: Coronuloidea). J. Mar. Biol. Assoc. UK, 93 (1): 143-182.

KIM, H.K., B.K.K. CHAN, C.B. KANG, H.W. KIM \& W. KIM. 2020. How do whale barnacles live on their hosts? Functional morphology and mating-group sizes of Coronula diadema (Linnaeus, 1767) and Conchoderma auritum (Linnaeus, 1767) (Cirripedia: Thoracicalcarea). J. Crustacean Biol., 40: 808-824.

KRÜGER, P. 1940. Cirripedia, Ascothoracida, Apoda. In: H.G. Bronns Klassen und Ordnungen des Tierreichs. Akademische Verlag, Leipzig.

LINNAEUS, C. 1758. Systema Naturae sive Regna Tria Naturae, secundum Classes, Ordines, Genera, Species, cum characteribus, differentiis, synonymis, locis, Editio decima, 
reformata. Laurentius Salvius, Stockholm.

LIU, R.Y. \& X.Q. REN, 2007. Fauna Sinica. Invertebrata. Vol. 42, Crustacea Cirripedia Thoracica. Science Press, Beijing.

MARX, F.G., O. LAMBERT \& M.D. UHEN. 2016. Cetacean paleobiology. John Wiley \& Sons, Chichester, 316 pp.

MONROE, R. 1981. Studies in the Coronulidae (Cirripedia) shell morphology, growth, and function, and their bearing on subfamily classification. Mem. Queensland Mus., 20: 237-251.

MONROE, R. \& R. GARRETT. 1979. Chelonibia testudinaria (L.) (Cirripedia, Coronulidae) on Crocodylus porosus Schneider, a new host record. - Crustaceana, 36 (1): 108.

MONTAGU, G. 1821. Description of a species of Delphinus, which appears to be new. Mem. Wernerian Nat. Hist. Soc., 3: 75-82.

MORIARTY, J.E., J.A. SACHS \& K. JONES. 2008. Directional locomotion in a turtle barnacle, Chelonibia testudinaria, on green turtles, Chelonia mydas. Mar. Turtle Newsl., 119: 1-4.

NEWMAN, W.A. \& A. ROSS. 1976. Revision of the balanomorph barnacles: including a catalog of the species. Mem. San Diego Soc. Nat. Hist., 9: 1-108.

NEWMAN, W.A. 1996. Cirripedia; Suborders Thoracica and Acrothoracica. In: J. Forest (Editor). Traité de Zoologie, Tome VII, Crustacés, Fascicule 2. Masson, Paris, pp. 453-540.

PERI, E., A. COLlareTA, G. INSACCO, G. \& G. BIANUCCI. 2019. An Inticetus-like (Cetacea: Odontoceti) postcanine tooth from the Pietra leccese (Miocene, southeastern Italy) and its palaeobiogeographical implications. N. Jb. Geol. Paläontol., 291 (2): 221-228.

PILSBRY, H.A. 1916. The sessile barnacles (Cirripedia) contained in the collections of the U.S. National Museum; including a monograph of the American species. Bull. U. S. Nat. Mus., 93: 1-366.

POKINES, J.T. \& N. HIGGS. 2015. Macroscopic taphonomic alterations to human bone recovered from marine environments. J. Forensic Ident., 65 (6): 953-984.

RANZANI, C. 1817. Osservazioni sui balanidi.
Opuscoli Scientifici, 2 (2): 63-69.

ROSS, A. 1963. Chelonibia in the Neogene of Florida. Q. J. Florida Acad. Sci, 26: 221-233. ROSS, A. \& M.G. FRICK 2011. Nomenclatural emendations of the family-group names Cylindrolepadinae, Stomatolepadinae, Chelolepadinae, Cryptolepadinae, and Tubicinellinae of Ross \& Frick, 2007- including current definitions of family-groups within the Coronuloidea (Cirripedia: Balanomorpha). Zootaxa, 3106: 60-66.

ROSS, A. \& C.G. JACKSON Jr 1972. Barnacle fouling of the ornate diamondback terrapin, Malaclemys terrapin macrospilota. Crustaceana, 22: 203-205.

ROSS, A. \& W.A. NEWMAN. 1967. Eocene Balanidae of Florida, including a new genus and species with a unique plan of "turtlebarnacle" organization. Am. Mus. Novitates, 2288: 1-21.

SACCO, F. 1893. Il delfino pliocenico di Camerano Casasco (Astigiana). Mem. Soc. Ital. Sci., 9: $1-15$.

SANTOS, A., E. MAYORAL \& F. MUÑIZ. 2005. Bioerosion scars of acorn barnacles from the southwestern Iberian Peninsula, upper Neogene. Riv. Ital. Paleontol. S., 111 (1): 181189.

SEILACHER, A. 2005. Whale barnacles: exaptational access to a forbidden paradise. Paleobiology, 31 (Suppl.): 27-35.

SLOAN, K., J.D. ZARDUS \& M.L. JONES. 2014. Substratum fidelity and early growth in Chelonibia testudinaria, a turtle barnacle especially common on debilitated loggerhead (Caretta caretta) sea turtles. Bull. Mar. Sci., 90 (2): 581-597.

SPENGLER, L. 1790. Beskrivelse og Oplysing over den hidindtil lidet udarbeide Slaegt af mangeskallede Konchylier, som Linnaeus har daldet Lepas, med tilfoiede nye og ubeskrevne Aeter (Om. Conchylie-Slaegten Lepas). Skrifter af Naturhistorie Selskabet, 1: 158-212.

TSAI, C.-H., A. COLLARETA, \& M. BOSSELAERS. 2020. A Pliocene gray whale (Eschrichtius sp.) from the eastern North Atlantic. Riv. Ital. Paleontol. S., 126 (1): 189-196. 
ZARDUS, J.D., D.T. LAKE, M.G. FRICK \& P.D. RAWSON. 2014. Deconstructing an assemblage of "turtle" barnacles: species assignments and fickle fidelity in Chelonibia. Mar. Biol., 161 (1): 45-59.
ZULLO, V.A. 1982. A new species of the turtle barnacle Chelonibia Leach, 1817 (Cirripedia, Thoracica) from the Oligocene Mint Spring and Byram Formations of Mississippi. Mississippi Geol., 2 (3): 1-6.

Received: 9 October 2020

Accepted:12 January 2021 


\title{
Pojava brumbuljka iz roda Chelonibia Leach, 1817, kao inkrustra na kosti sisavca u središnjem dijelu Sredozemnog mora
}

\author{
Alberto COLLARETA* i Giovanni BIANUCCI \\ *Kontakt, e-pošta: alberto.collareta@unipi.it
}

\begin{abstract}
SAŽETAK
Među kornjačama i kitovima (Coronuloidea: Chelonibiidae, Coronulidae, $†$ Emersoniidae i Platylepadidae), pripadnici vrste Chelonibia testudinaria (Linnaeus, 1758) poznati su kao epizoični brumbuljci koji se mogu pričvrstiti na prilično širok spektar podloga (prvenstveno na kornjače, rakove i velike vodene sisavce koji se hrane biljkama iz reda Sirenia).

Trenutno su prepoznate tri živa morfija $C$. testudinaria; od njih, manje specifična za domaćina je morph patula, koja također prikazuje izuzetno jednostavnu, nespecijaliziranu arhitekturu ljuske.

U ovom radu izvještavamo o nekoliko ljuski helonibiida, koje se odnose na morfe patule $C$. testudinaria, koja inkrustira lopaticu kitova sakupljenu s dna Jadranskog mora prema Salentu (regija Apulia, jugoistočna Italija) i okvirno upućenu na Tursiops truncatus (Montagu, 1821).

Ovo je jedan od rijetkih zapisa u svijetu o brumbuljku iz nežive podloge, a i kao drugi slučaj inkrustriranja na kosti sisavca. Takva neobična pojava potom se ukratko raspravlja u širem kontekstu komensalizma brumbuljaka i supstrata staništa.
\end{abstract}

Ključne riječi: Cirripedia; Chelonibiidae; epibiosis; preferencije domaćina; simbioza; kornjača 